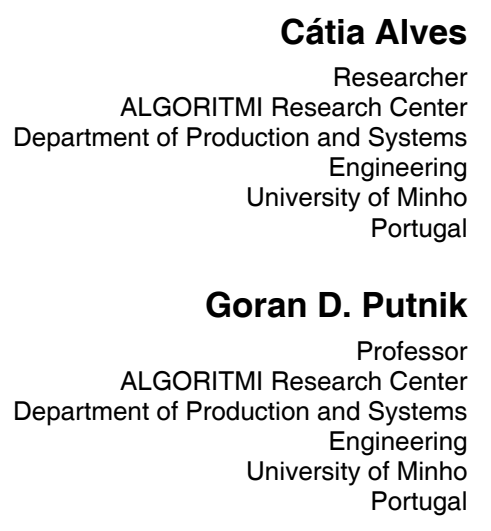

Cátia Alves

arch Cente

Engineering

of Minho

\section{Cyber-Physical Production System (CPPS) Decision Making Duration Time Impact on Manufacturing System Performance}

Cyber-Physical Production Systems (CPPS) are inherent to i4.0 to enhance actual manufacturing system control and management processes, and, consequently, the decision making process. This paper presents research on the influence of decision making duration time in CPPS on manufacturing system performance, for different scheduling paradigms. Different scenarios were investigated considering different decision making duration times and different variations of the environement dynamics. Results show that with the increase of the decision making duration time, the completion time of the jobs given at the input, as one of the principal manufacturing system performance measures, increases. Also, considering stable environments, the completion time variation growth in function of CPPS decision making duration time is approximately linear, while when considering dynamic environments, completion time variation growth in the function of CPPS decision making duration time is nonlinear.

Keywords: Cyber-Physical Production System, Industry 4.0, Decision Making Duration Time, Scheduling, Completion Time, Environment Dynamics

\section{INTRODUCTION}

The development of Cyber-Physical Production Systems (CPPS) is inherent to i4.0 in order to enhance actual manufacturing system control and management processes, and, consequently, the decision making process, with the new characteristics of i4.0, such as digitalization and connectivity of the production systems through the embedding Information and Communication Technologies (ICT).

Within the context of the decision making process, one of the features that impacts manufacturing system performance is the decision making duration time in scheduling.

The aim of this paper is the evaluation of the decision making duration time impact on the manufacturing system performance, under the context of i4.0.

Although the impact of decision making duration time "shortening" seems logical, it was observed that in traditional manufacturing systems (up to i3.0) it is not so relevant, or it was virtually not considered, as a factor in scheduling planning, for the scenario of i4.0 it is expected that shorter decision making duration time impacts positively manufacturing system performance.

In the scenario, or context, of i4.0, due to the capacity of data collection in real time, emerged the need for manufacturing system control in real time as well. With

Received: November 2018, Accepted: June 2019

Correspondence to: Dr Cátia Alves. ALGORITMI

Research Center, University of Minho Campus of Azurém, 4800-058 Guimarães. Portugal

E-mail: catia.alves@dps.uminho.pt

doi:10.5937/fmet1904675A

(C) Faculty of Mechanical Engineering, Belgrade. All rights reserved the control in real time, emerges also the need to have more points of decision making, i.e. much higher frequency of decision making on rescheduling, than before.

The high frequency of decision making on re-scheduling, for i4.0 scenarios, suggests, further, the need to control the decision making duration time.

The development of new ICT tools and services, in the context of i4.0, allows the decision making duration time's significant reduction (if not elimination at all). The question is if the reduction of decision making duration time has an impact or not on manufacturing system performance, and if yes, what is the amplitude of this impact.

Concerning these new requirements and question on decision making duration time impact on manufacturing system performance, the following research hypotheses are formulated:

1. Shorter CPPS decision making duration time provides higher manufacturing system performance, and

2. The environment dynamics is a factor of completion time variation in function of CPPS decision making duration time.

The paper is further organized as follows. An introduction to CPPS and a description of CPPS in the context of this paper is given in Chapter 2. Chapter 3 presents an abstract (graphical ad hoc) model of the decision making duration time in CPPS as well as its impact on completion time, as the measure of the manufacturing system performance. The experimental plan and the results are presented in Chapter 4. The result analysis is given in Chapter 5. Chapter 6 presents conclusions. 


\section{DECISION MAKING FUNCTION IN TRADITIONAL MANUFACTURING SYSTEMS AND CYBER- PHYSICAL PRODUCTION SYSTEMS}

\subsection{Decision making function in traditional manufac- turing systems}

Traditional manufacturing systems are informed by cybernetics implying feedback loops for controlling it. There is a number of feedback loops in manufacturing systems for controlling different functionalities, e.g. machine tools movement controlling servosystems for/ and interpolations, production planning and control, security control, energy consumption control, quality control, etc.

These multiple feedback loops are symbolically presented in Figure 1.

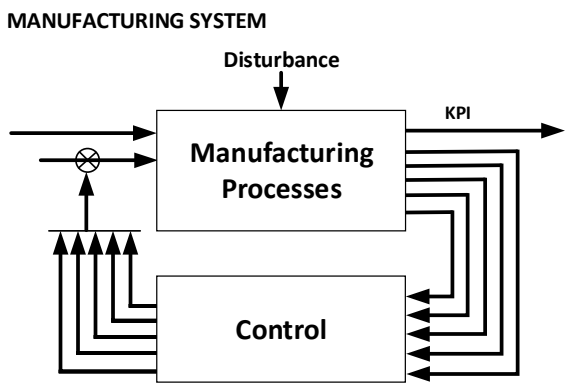

Figure 1. Traditional manufacturing system logical architecture [1]

Decision making function in traditional manufacturing systems is a part of the feedback loops, embedded in the "control" block in Figure 1.

While the so-called "primitive", or "low level", feedback loops, such as servocontrol, could be realized in real time, the "higher level" feedback loops in traditional manufacturing systems, such as, typically, production planning and control, are realized in batch mode, or offline mode.

In this sense, concerning production planning and control, control loops, and corresponding decision making processes, affect the manufacturing system behavior and architecture, through adaptations and reconfigurations, but in batch mode, or offline mode.

This form of traditional manufacturing system control, i.e. the manufacturing system control, including adaptations and reconfigurations, and corresponding decision makings, in batch mode, or offline mode, nowadays is considered as a limitation. To overcome this limitation Cyber-Physical Systems (CPS), more particularly Cyber-Physical Production Systems (CPPS), are conceived.

\subsection{Cyber-Physical Production Systems (CPPS)}

One of the CPPS definitions, which we will consider as reference definition in this paper, is given in [2]: "CPS are integrations of computation with physical processes. Embedded computers and networks monitor and control the physical processes, usually with feedback loops where physical processes affect computations and vice versa".

Adaptability, reconfigurability, fast responsiveness, and robustness are some advantages of CPPS, once traditional systems cannot "respond quickly enough to a large-scale system because of the lack of agility and dynamic behavior, which are necessary to address complex and changeable system environments" [3].

In other words, the main difference between traditional manufacturing systems, without CPPS, and manufacturing systems with CPPS, is the CPPS capability of real time decision making concerning adaptability, reconfigurability, fast responsiveness, and robustness, with additional functionalities of capability for "feedback loops where physical processes affect computations and vice versa".

These differences imply specific logical functional architecture of the CPPS, in comparison with traditional manufacturing system logical architecture presented in Figure 1.

The specific logical functional architecture of the CPPS adopted in this research is presented in Figure 2, which corresponds to the level $\mathrm{CPS}^{0}$ within the "CPS spectrum" [1].

The $\mathrm{CPS}^{0}$ is the "integration of the computation with physical processes" in which the computational processes (referred as "Digital Processes 0" Layer) affects the physical processes (referred as "Physical Processes" Layer) of the CPPS through feedback loops, creating new instances of the Manufacturing System (Figure 3) at each loop or reconfiguration $\left(\operatorname{tr}_{n}\right)$.

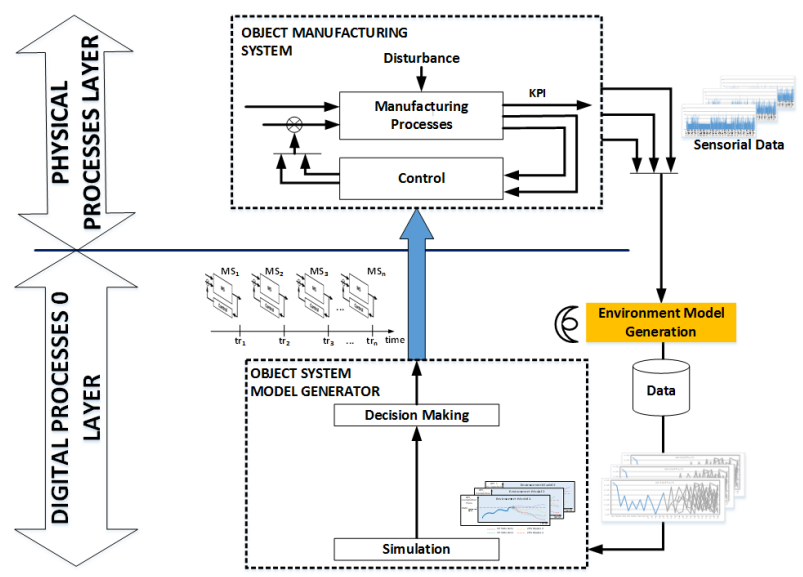

Figure 2. CPPS logical architecture [1]

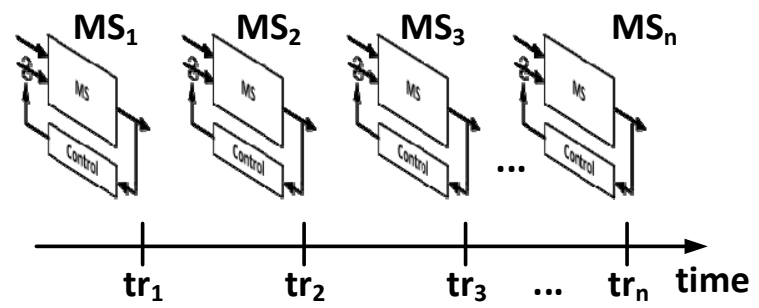

Figure 3. Manufacturing System instances [1]

The Manufacturing System in the CPPS, which includes physical processes (but also includes the low level digital processes of control which are not allocated to the new CPS's digital layer), is called "Object Manufacturing System", as it is the object of change in each feedback loop (or instance).

In the CPPS some of the feedback loops in manufacturing systems for controlling different functionalities are kept within the "Object Manufacturing System", while some of the controlling functionalities are the input 
for the simulations and decision making processes within the computational part. The sensorial data capture of the controlling functionalities, for the simulations and decision making processes, is collected through the implementation of sensors. See e.g. [4] for some aspects of sensors as smart objects for decision making functions.

In order to provide the capacity of simulations over the same scenarios, the "Environment Model Generation" is considered. Uncertainty of the environment dynamics is addressed for example in [5,6].

The "Digital Processes 0" computational processes of the CPPS comprises the module "Object System Model Generator" with the simulation and decision making functionalities. Within the specific logical functional architecture of the CPPS, the decision making function is related to simulation functionality as represented in Figure 2.

The CPPS decision making function is related to learning as well but in the $\mathrm{CPS}^{1}$ architecture model, which is not issued in this paper. $\mathrm{CPS}^{1}$ and $\mathrm{CPS}^{2}$ architectures models are discussed in [1].

\subsection{Decision making function in CPPS}

The decision making function in CPPS has a different function when compared to the traditional manufacturing systems. The main function is that the decision making within the digital/computational processes of the CPPS, affects the physical part of the manufacturing system behaviour and architecture, through feedback loops, through adaptations and reconfigurations, in online mode.

One change in the manufacturing system could be, for example, changing the planning of the production scheduling during a reconfiguration, also called rescheduling.

Rescheduling and/or reconfiguration requires time for its planning. In the context of this paper, the rescheduling and/or reconfiguration time is interpreted as decision making duration time in the CPPS.

\section{DECISION MAKING DURATION TIME IN CPPS}

\subsection{Decision making duration time for different scheduling paradigms}

The decision making duration time is a feature that impacts manufacturing system performance.

Considering the decision making function in CPPS, the decision making duration time could be embedded in different scheduling paradigms.

These different scheduling paradigms could be classified in function of the length and/or type of planning horizon, and the existence of reconfigurations (Table 1), as "Fixed Horizon Scheduling", "Fixed Horizon Scheduling with Reconfigurations", "Rolling Horizon Scheduling" and "Real Time Management Scheduling".

The planning horizon could be interpreted as the time for execution of the scheduling for a specific interval which is delimited by the projected completion time, e.g. delimited by the time required to complete all tasks of all jobs scheduled.

The Decision Making Duration Time (DMDT) for the fixed horizon scheduling paradigms is presented in
Figure 4. Note that the executed schedule corresponds to the sum of the Executed Planned Schedule (EPS) plus the delay (the delay will be addressed in the next section of this paper).

Table 1. Scheduling paradigms classification

\begin{tabular}{|c|c|c|c|}
\hline $\begin{array}{c}\text { Type of } \\
\text { scheduling } \\
\text { paradigm }\end{array}$ & $\begin{array}{c}\text { Planning } \\
\text { Horizon }\end{array}$ & Length & Reconfiguration \\
\hline $\begin{array}{c}\text { Fixed Horizon } \\
\text { Scheduling }\end{array}$ & Fixed & $\begin{array}{c}\text { Delimited by the } \\
\text { number of jobs } \\
\text { concluded }\end{array}$ & No \\
\hline $\begin{array}{c}\text { Fixed Horizon } \\
\text { Scheduling with } \\
\text { Reconfigurations }\end{array}$ & Fixed & $\begin{array}{c}\text { Delimited by the } \\
\text { number of jobs } \\
\text { concluded }\end{array}$ & Yes \\
\hline $\begin{array}{c}\text { Rolling Horizon } \\
\text { Scheduling }\end{array}$ & Rolling & $\begin{array}{c}\text { Delimited by the } \\
\text { rolling period }\end{array}$ & Yes \\
\hline $\begin{array}{c}\text { Real Time } \\
\text { Management } \\
\text { Scheduling }\end{array}$ & Rolling & $\begin{array}{c}\text { Delimited by the } \\
\text { reconfiguration } \\
\text { period }\end{array}$ & Yes \\
\hline
\end{tabular}

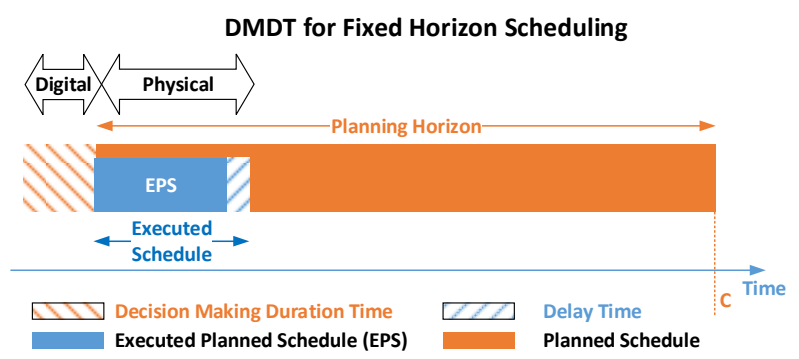

Figure 4. DMDT for Fixed Horizon Scheduling

When a delay occurs, it is necessary to reconfigure (the terms re-planning and re-scheduling could be used as synonyms in this context). Other reasons for reconfiguration exist as well, such as re-evaluation of machine efficiency, requests by clients, etc..

The reconfiguration is to be made from the point of time when it is necessary to reconfigure (because of the delay) until the completion time value (C) of all remaining jobs. This implies the "Fixed Horizon Scheduling with Reconfiguration" paradigm.

Figure 5 shows the DMDT within the Fixed Horizon Scheduling with Reconfiguration paradigm.

In the case of the "Rolling Horizon Scheduling" paradigm, the planning horizon is equal to the rolling horizon (lesser than planning horizon in "Fixed Horizon").

The decision for the reconfiguration is made on the same basic and rationality as for the "Fixed Horizon Scheduling with Reconfigurations", except that the planning horizon is lesser, and that for the following reconfiguration the planning horizon "rolls" forward, which is the reason why the planning horizon is called "rolling horizon" in this paradigm.

Figure 6 shows the DMDT within the Rolling Horizon Scheduling paradigm.

Both figures (Figure 5 and Figure 6) have presented three feedback loops in the context of CPPS, i.e. three decision making processes, at three moments: one for decision on initial configuration and two for decisions for two reconfigurations.

However, these cases are not CPPS in its maximum capacity. From the authors' point of view, this is the "control" process that is also presented within the traditional manufacturing system (Figure 1). 
DMDT for Fixed Horizon Scheduling with reconfiguration

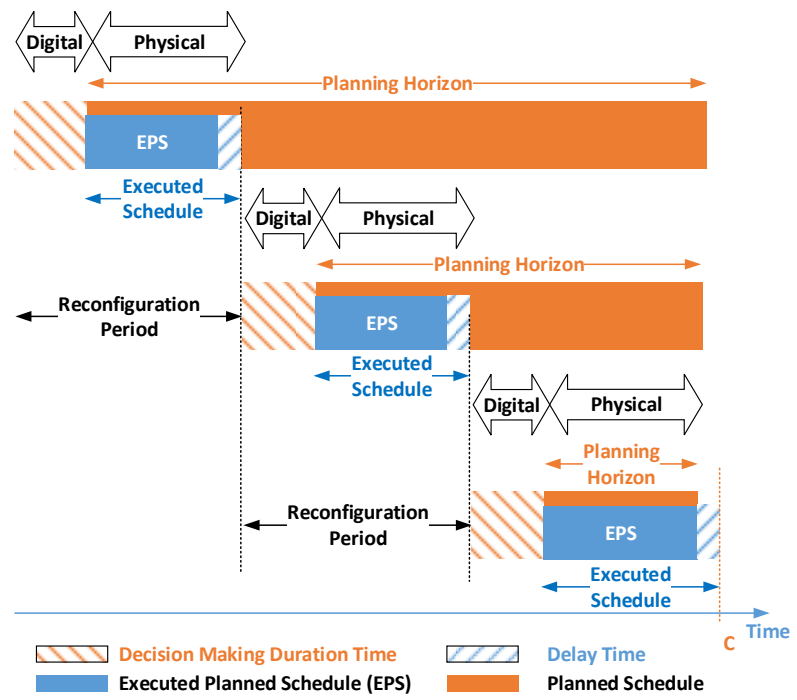

Figure 5. DMDT for Fixed Horizon Scheduling with reconfiguration

DMDT for Rolling Horizon Scheduling

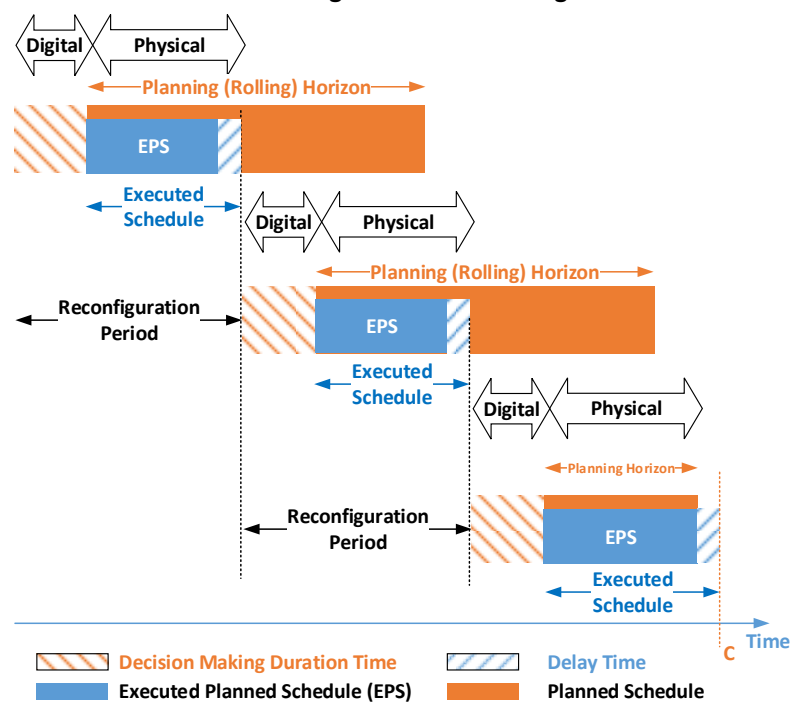

Figure 6. DMDT for Rolling Horizon Scheduling

DMDT for Real Time Management Scheduling

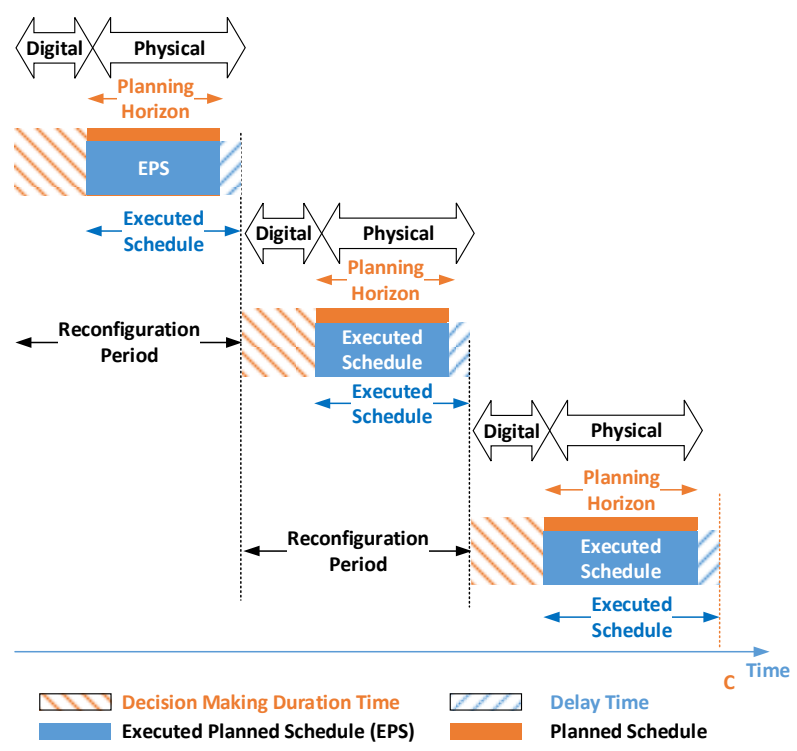

Figure 7. DTDM for Real Time Management Scheduling
The CPPS is used in its maximum capacity when manufacturing data is collected in real time, through sensors, and decision making (based on simulation results) is in real time. This implies the "Real Time Management Scheduling".

Figure 7 shows the DMDT within the Real Time Management Scheduling paradigm.

\subsection{Modelling decision making duration time and cumulative delay}

Another measure that impacts the manufacturing system performance is delay.

The accumulation of delays results in lowering the productivity of the manufacturing system. In [7] rescheduling is considered as a measure to reduce the delays.

The delay parameter, named Delay Time $D(t)$, is modelled in accordance with the cumulative delay time function proposed by [8]:

$$
D(t)=a t^{b}
$$

while the calculation of parameters $a$ and $b$ is given in [9].

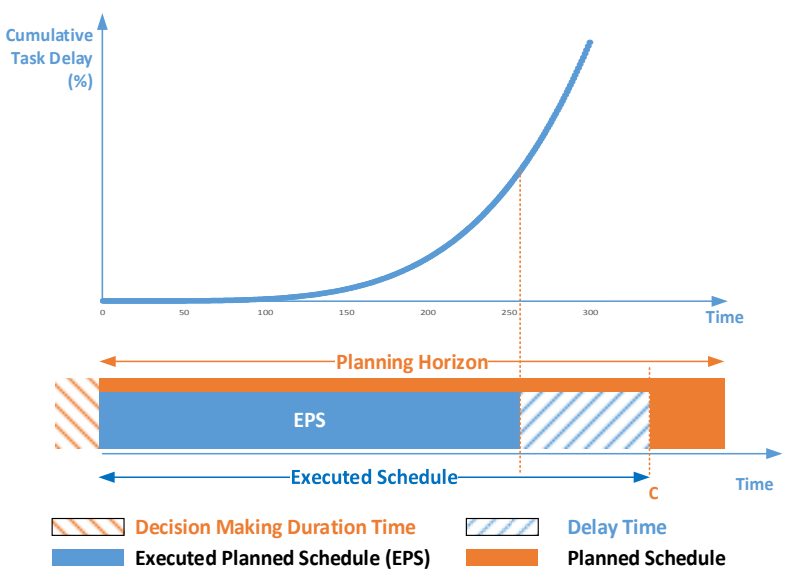

Figure 8. Cumulative delay effect

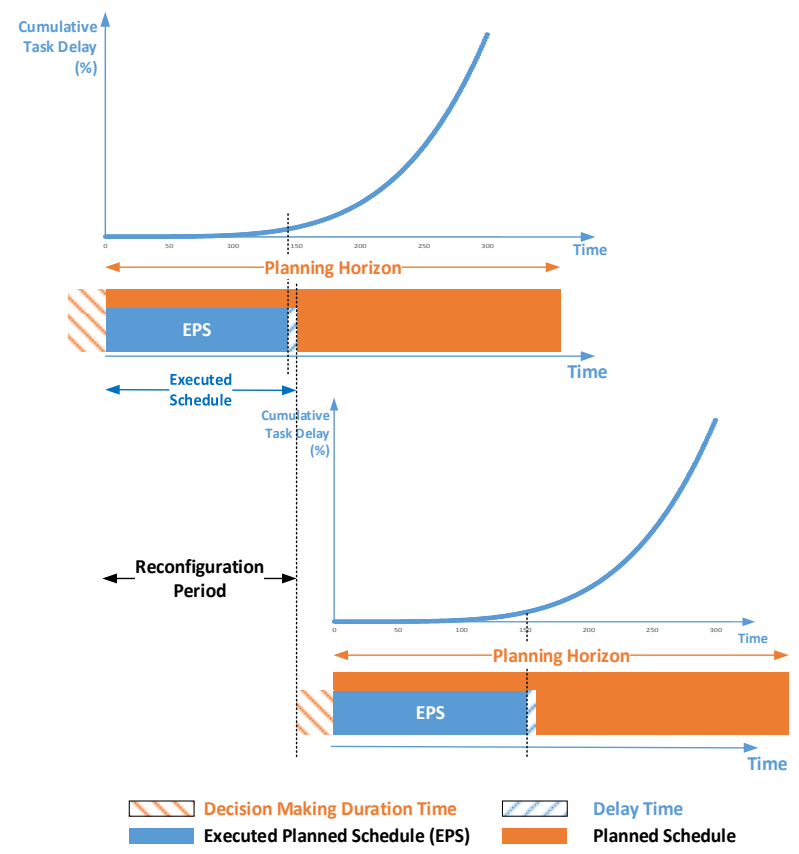

Figure 9. Cumulative delay value as a trigger for decision making on reconfiguration 
Figure 8 presents the delay time, i.e. time of delaying calculated/planned completion time which (the delay time) is in the function of the Executed Planned Schedule elapsed time. Obviously, it is a nonlinear function, in the sense that delay gradient growth with time.

Monitoring of the Delay Time parameter, i.e. the cumulative delay along the time, is used to determine the time moment for the schedule revision, in accordance with the management policy (the use of monitoring in scheduling is also addressed in [10]). Additionally, its nature implies shorter simulations periods, i.e. shorter intervals between two object system's feedback loops, or, shorter periodicity of reconfigurations, or, higher frequency of decision making and consequent reconfigurations, Figure 9.

\subsection{Decision making duration time and cumulative delay in CPPS}

The described measures, decision making duration time and cumulative delay, which impact the manufacturing system performance, are valid for the traditional manufacturing systems (i3.0) as well as for the new approaches to the manufacturing system within the i4.0 context.

In the scenario of $\mathrm{i} 4.0$, emerges the need to collect data in real time to control, in real time, the manufacturing process, leading to the increase of points of decision making. Additionally, high decision making frequency on re-scheduling, implies shorter cumulative delay as seen in the previous section. High decision making frequency is achieved by the "Real Time Management Scheduling" paradigm, presented in Figure 7.

These two manufacturing system performance measures will be considered for hypotheses validation.

\section{CPPS DECISION MAKING TIME EFFECT STUDY}

\subsection{Study outline}

This study aims to evaluate the decision making duration time impact of the on manufacturing system performance, in the context of i4.0.

The research hypotheses are formulated in section 1 (Introduction).

In this study, the environment dynamics is also considered for validation. The data generation on environment dynamics included different variations of nominal process plan input data amplitude, consisted on variations of: $0 \%$ (no variation), $50 \%$ (processing time variation of $50 \%$ from the nominal process plan input data), and 100\% (processing time variation of $100 \%$ from the nominal process plan input data). The nominal process plan describes all the operations (tasks) for all the jobs, and the values of processing time for each candidate machine.

Secondary data was considered for validation as a reference data for all the simulations, within the scientific research context as a valid data (other data could also be considered). These data were selected to provide as well the reference to other research published in other papers (at this moment, the state of the art review didn't find any reference to the research subject of this paper).

The scenario for the nominal process plan input data is taken from the literature case, based on data presented by [11], considering the optimal process plan for each job result obtained.
The values for the process plans considered in this paper are given in Table 2. Each cell in Table 2 contains the data of the candidate machine (rounded parentheses) and the processing times on correspondent candidate machines (square parentheses), respectively. For example, the operation $1(\mathrm{O} 1)$ from the first process plan (pr1,2), takes 4 units of time if it is processed on candidate machine 1 , or takes 5 units of time if it is processed on candidate machine 3 .

There are used non-dimensional units of time.

\subsection{Scenarios for validation}

Different scenarios were investigated for the hypotheses validation, considering the secondary data (from literature), and the following parameters:

- Decision Making Duration Time in CPPS values: $\{0$, $1,2,5,8,10\}$

- Number of jobs concluded: $\{10,20,40,100\}$;

- Number of resources (machines): 8 ;

- Maximum number of operations per process plan: 8;

- Data generation on environment dynamics (including different variations of operations/tasks processing time as input), in comparison with the original secondary data considered as the nominal process plans, by the following values of variations: $0 \%$ (no variation), $50 \%$ and $100 \%$;

- Model considered: decision making duration time for real time management scheduling;

- Reconfiguration period (between 2 reconfigurations): 15 units of time.

\subsection{Simulations and results}

Simulations ran at the computer Intel ${ }^{\circledR}$ Core $^{\mathrm{TM}}$ i7-7700 CPU@3.60GHz, 32.0 Gb (RAM), Operating System: Windows 10. 74 simulations in total were conducted.

The simulator was developed by the authors, in $\mathrm{C}++$, with the NetBeans software.

The experimental results for all simulations are summarized in Table 3. The simulation results diagrams are presented in Figure 10, Figure 11 and Figure 12.

As the reconfiguration period is equal to 15 units of time, and by following the Delay Time function, the value of cumulative delay time is very small: 0,005238 units of time (considering the data values from [8] for the estimated parameters $a$ and $b$ for the instance $\mathrm{I}(8,120,1.3,0.1,1)$. For this reason, the cumulative value was not considered in the results presented, as they have a very low impact on the final results.

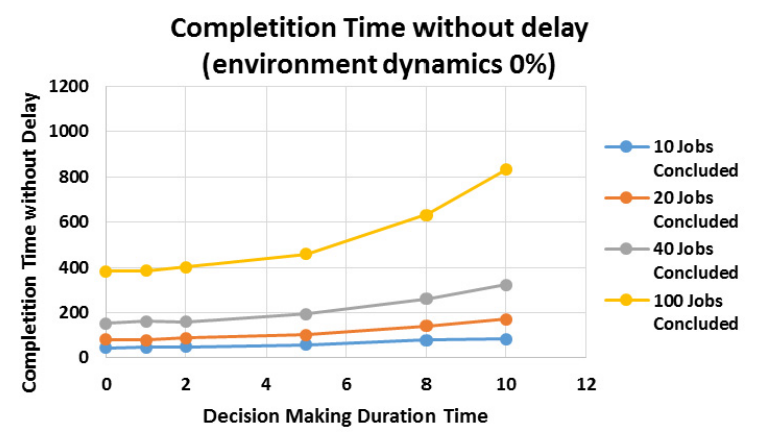

Figure 10. Completion time without delay for environment dynamics of $0 \%$ 
Table 2. Process plan decision data for $8 \times 8$ problem (adapted from [11])

\begin{tabular}{|c|c|c|c|c|c|c|c|}
\hline \multirow{2}{*}{ Process Plan } & \multicolumn{7}{|l|}{ Operation } \\
\hline & 01 & O 2 & O 3 & O 4 & O5 & 06 & O 7 \\
\hline pr1,2 & $\begin{array}{l}(1,3) \\
{[4,5]}\end{array}$ & $\begin{array}{l}(2,4) \\
{[4,5]}\end{array}$ & $\begin{array}{l}(3,5) \\
{[5,6]}\end{array}$ & $\begin{array}{l}(4,5,6,7,8) \\
{[5,5,4,5,9]}\end{array}$ & & & \\
\hline pr2,2 & $\begin{array}{l}(1,3,5) \\
{[1,5,7]}\end{array}$ & $\begin{array}{l}(4,8) \\
{[5,4]}\end{array}$ & $\begin{array}{l}(4,6) \\
{[1,6]}\end{array}$ & $\begin{array}{l}(4,7,8) \\
{[4,4,7]}\end{array}$ & $\begin{array}{l}(4,6) \\
{[1,2]}\end{array}$ & $\begin{array}{l}(1,6,8) \\
{[5,6,4]}\end{array}$ & $\begin{array}{l}\text { (4) } \\
{[4]}\end{array}$ \\
\hline pr3,3 & $\begin{array}{l}(2,3,8) \\
{[7,6,8]}\end{array}$ & $\begin{array}{l}(4,8) \\
{[7,7]}\end{array}$ & $\begin{array}{l}(3,5,7) \\
{[7,8,7]}\end{array}$ & $\begin{array}{l}(4,6) \\
{[7,8]}\end{array}$ & $\begin{array}{l}(1,2) \\
{[1,4]}\end{array}$ & & \\
\hline pr 4,2 & $\begin{array}{l}(1,3,5) \\
{[4,3,7]}\end{array}$ & $\begin{array}{l}(2,8) \\
{[4,4]}\end{array}$ & $\begin{array}{l}(3,4,6,7) \\
{[4,5,6,7]} \\
\end{array}$ & $\begin{array}{l}(5,6,8) \\
{[3,5,5]}\end{array}$ & & & \\
\hline $\operatorname{pr} 5,1$ & $\begin{array}{l}(1) \\
{[3]}\end{array}$ & $\begin{array}{l}(2,4) \\
{[4,5]}\end{array}$ & $\begin{array}{l}(3,8) \\
{[4,4]}\end{array}$ & $\begin{array}{l}5,6,8) \\
{[3,3,3]}\end{array}$ & $\begin{array}{l}(4,6) \\
{[5,4]}\end{array}$ & & \\
\hline pr6,3 & $\begin{array}{l}(1,2,3) \\
{[3,5,6]}\end{array}$ & $\begin{array}{l}(4,5) \\
{[7,8]}\end{array}$ & $\begin{array}{l}(3,6) \\
{[9,8]}\end{array}$ & & & & \\
\hline pr7,2 & $\begin{array}{l}(3,5,6) \\
{[4,5,4]}\end{array}$ & $\begin{array}{l}(4,7,8) \\
{[4,6,4]}\end{array}$ & $\begin{array}{l}(1,3,4,5) \\
{[3,3,4,5]}\end{array}$ & $(4,6,8)[4,6,5]$ & $\begin{array}{l}(1,3) \\
{[3,3]}\end{array}$ & & \\
\hline pr8,1 & $(1,2,6)[3,4,4]$ & $(4,5,8)[6,5,4]$ & $(3,7)[4,5]$ & $(4,6)[4,6]$ & $\begin{array}{l}(7,8) \\
{[1,2]}\end{array}$ & & \\
\hline
\end{tabular}

Table 3. Completion time without delay time results

\begin{tabular}{|c|c|c|c|c|c|c|c|c|c|c|c|c|c|}
\hline \multirow{2}{*}{\multicolumn{2}{|c|}{\begin{tabular}{|r|}
$N^{0}$ of Jobs concluded \\
\end{tabular}}} & 10 & 20 & 40 & 100 & 10 & 20 & 40 & 100 & 10 & 20 & 40 & 100 \\
\hline & & \multicolumn{4}{|c|}{$\begin{array}{c}\text { Data generation on } \\
\text { environment dynamics } 0 \%\end{array}$} & \multicolumn{4}{|c|}{$\begin{array}{c}\text { Data generation on } \\
\text { environment dynamics } 50 \%\end{array}$} & \multicolumn{4}{|c|}{$\begin{array}{c}\text { Data generation on } \\
\text { environment dynamics } 100 \%\end{array}$} \\
\hline \multirow{6}{*}{ 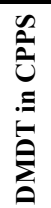 } & 0 & 46 & 82 & 154 & 383 & 63 & 100 & 199 & 474 & 69 & 128 & 235 & 561 \\
\hline & 1 & 47 & 81 & 164 & 387 & 63 & 107 & 199 & 482 & 69 & 120 & 221 & 562 \\
\hline & 2 & 49 & 90 & 161 & 402 & 69 & 107 & 199 & 503 & 78 & 123 & 234 & 572 \\
\hline & 5 & 60 & 104 & 194 & 460 & 76 & 132 & 228 & 570 & 78 & 123 & 234 & 572 \\
\hline & 8 & 81 & 142 & 261 & 632 & 94 & 170 & 308 & 739 & 94 & 185 & 334 & 834 \\
\hline & 10 & 84 & 173 & 323 & 833 & 116 & 199 & 380 & 955 & 128 & 199 & 426 & 1015 \\
\hline
\end{tabular}

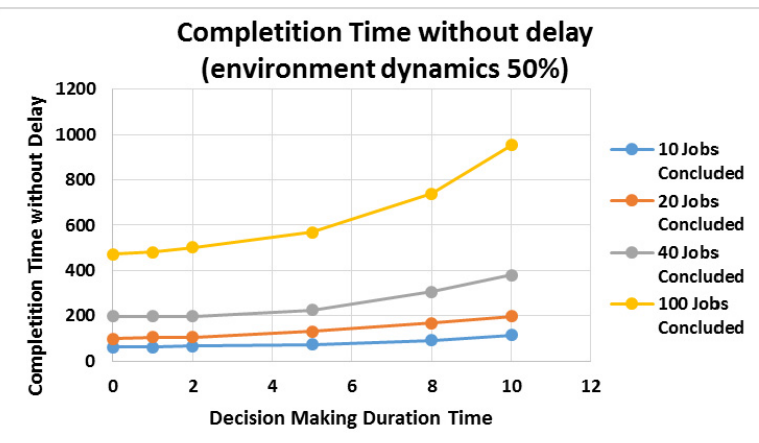

Figure 11. Completion time without delay for environment dynamics of $50 \%$

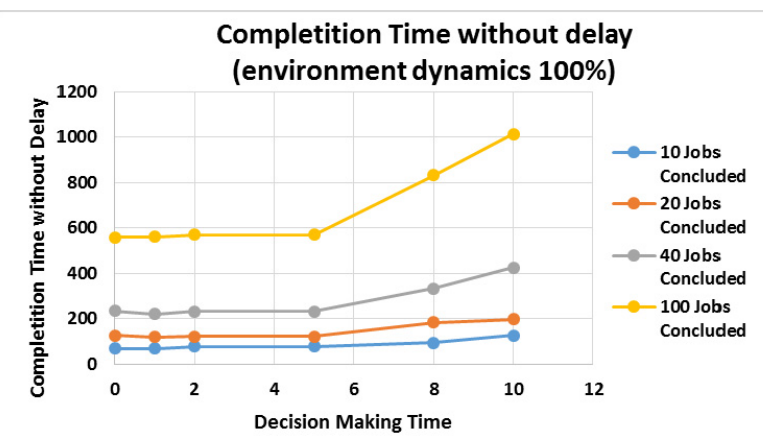

Figure 12. Completion time without delay for environment dynamics of $100 \%$

\section{RESULTS ANALYSIS}

Results show that with the increase of the decision making duration time, the completion time of the jobs given at the input, as one of the principal manufacturing system performance measures, increases. This validates the hypothesis 1 . that shorter CPPS decision making duration time provides higher manufacturing system performance.

Evaluation of the decision making duration time impact amplitude, as percentage in comparison with the case when the decision making duration time is equal to zero (0), are presented in Figure 13, Figure 14 and Figure 15 , considering the different environment dynamics of $0 \%, 50 \%$ and $100 \%$, respectively.

Considering stable environments, the completion time variation grows, in function of CPPS decision making duration time, approximately linearly (Figure 13 and Figure 14), while when considering dynamic environments, completion time variation growth, in function of CPPS decision making duration time, is nonlinear (Figure 15). These results confirm that environment dynamics is a factor of completion time variation in function of CPPS decision making duration time, positively confirming the second research hypothesis.

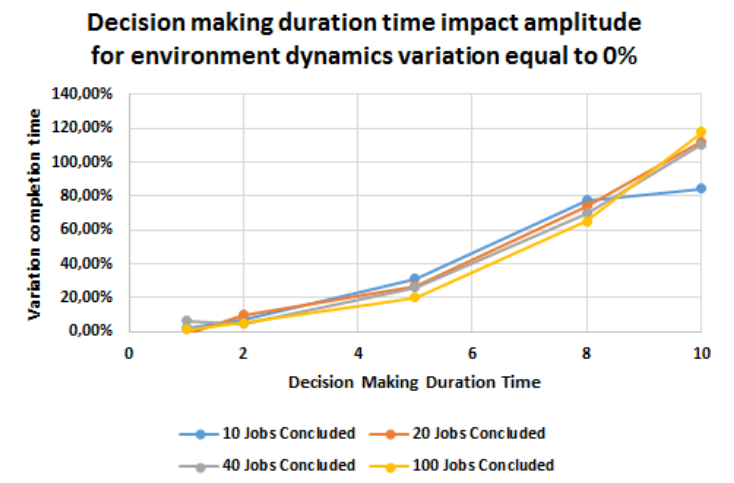

Figure 13. Decision making duration time impact amplitude for environment dynamics $0 \%$ 


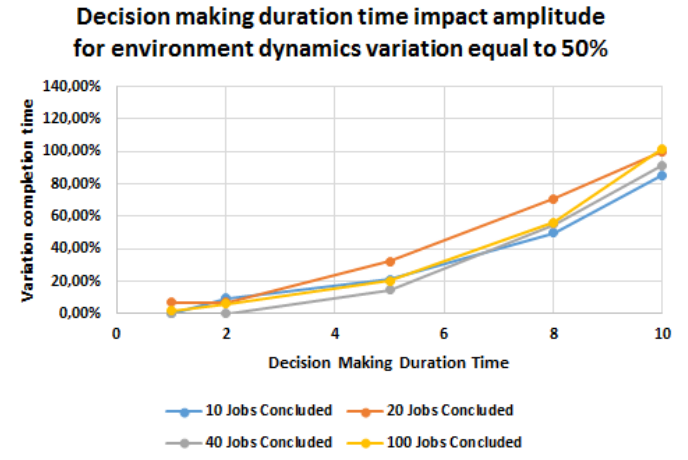

Figure 14. Decision making duration time impact amplitude for environment dynamics $\mathbf{5 0 \%}$

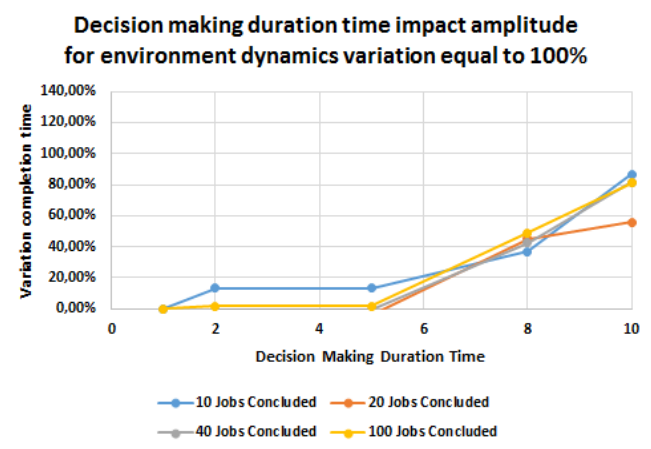

Figure 15. Decision making duration time impact amplitude for environment dynamics $100 \%$

\section{CONCLUSION}

This paper evaluated the decision making duration time in CPPS as a factor in manufacturing system performance, under the context of the new requirements of i4.0.

Research hypotheses have been positively validated, i.e. shorter CPPS decision making duration time provides higher manufacturing system performance, and environment dynamics is a factor of completion time variation in function of CPPS decision making duration time.

This positive validation of the research hypotheses demonstrates the need to consider the decision making duration time control in CPPS in real time, in the context of i4.0., implying employment of advanced computational resources, hardware, and software, that are capable of providing decision making in real time, i.e. virtually in less than a second.

Concerning modelling of scheduling function in i4.0 environments, further research could address the evaluation of the impact of decision making duration time on other manufacturing system performance measures, such as cost and $\mathrm{CO}_{2}$ emissions; $\mathrm{CO}_{2}$ emissions as performance measure is a critical factor of sought sustainability of manufacturing systems.

\section{ACKNOWLEDGMENT}

This work has been supported by FCT - Fundação para a Ciência e Tecnologia, Portugal, within the Project Scope: UID/CEC/00319/2019.

\section{REFERENCES}

[1] Putnik, G. D., Ferreira, L., Lopes, N., Putnik, Z.: What is Cyber-Physical System: Definitions and
Models Spectrum, FME Transactions, Vol. 47 No. 4, pp. 663-674, 2019.

[2] Lee, E. A.: Cyber physical systems: Design challenges, in: 2008 11th IEEE International Symposium on Object and Component-Oriented Real-Time Distributed Computing (ISORC), 2008, Orlando, pp. 363-369.

[3] Jiang, Z., Jin, Y., Mingcheng, E., and Li, Q.: Distributed Dynamic Scheduling for CyberPhysical Production Systems Based on a MultiAgent System. IEEE Access, Vol. 6, pp. 18551869, 2018.

[4] Putnik, G. D., Varela, M. L. R., Carvalho, C., Alves, C., Shah, V., Castro, H., and Ávila, P.: Smart objects embedded production and quality management functions, International Journal for Quality Research, Vol. 9, No. 1, pp. 151-166, 2015.

[5] Arrais-Castro, A., Varela, M. L. R., Ribeiro, R. A., and Putnik, G. D.: Spatial-temporal business partnership selection in uncertain environments, FME Transactions, Vol. 43, No. 4, pp. 353-361.

[6] Alves, C.: Modelling and Evaluation of "Fixed Horizon", "Rolling Horizon" and "Real Time Management" Production Scheduling Paradigms in Ubiquitous Production Networks under Conditions of Dynamic Environments for Economic and Environmental Sustainability., $\mathrm{PhD}$ thesis, School of Engineering, University of Minho, Guimarães, 2017.

[7] Suwa, H.: A new when-to-schedule policy in online scheduling based on cumulative task delays, International Journal of Production Economics, Vol. 110, No. 1, pp.175-186, 2007.

[8] Suwa, H. and Sandoh, H.: Capability of cumulative delay based reactive scheduling for job shops with machine breakdowns. Computers \& Industrial Engineering. Vol. 53, No. 1, pp. 63-78, 2007.

[9] Weisstein, E.W.: Least Squares Fitting--Power Law, Retrieved 16 June 2017, Available from: http://mathworld.wolfram.com/LeastSquaresFitting PowerLaw.html.

[10] Klarin, M. M., Misita, M. Ž., Spasojević-Brkić, V. K.: Desing of multi-dimensional model of production scheduling and monitoring in metal industry, FME Transactions. Vol. 30, No. 1, pp. 29-34, 2002.

[11]Zhou, G., Xiao, Z., Jiang, P., and Huang, G. Q.: A game-theoretic approach to generating optimal process plans of multiple jobs in networked manufacturing, International Journal of Computer Integrated Manufacturing, Vol. 23, No. 12, pp. 1118-1132, 2010.

\section{УТИЦАЈ ВРЕМЕНА ТРАЈАҢА ДОНОШЕЫА ОДЛУКА У САЈБЕР-ФИЗИЧКИМ ПРОИЗВОДНИМ СИСТЕМИМА (СФПС) НА ПЕРФОРМАНСЕ ПРОИЯВОДНОГ СИСТЕМА}


Сајбер-Физички Производни Системи (СФПС) су инхерентни Индустрији 4.0 како би се унапредили ктуаелни процеси управљања и контроле производним системом, а самим тим и процес доношења одлука. Овај рад представља истраживање утицаја времена трајања доношења одлука у СФПС на перформансе производног система, за различите парадигме планирања производње. Испитивани су различити сценарији с обзиром на различита времена трајања одлучивања и различите варијације дина- мике окружења. Резултати показују да се са повећањем времена трајања одлучивања повећава време завршетка послова датих на улазу, као једна од главних мера перформанси производног система. Такође, узимајући у обзир стабилна окружења, раст варијације времена завршетака у функцији времена трајања одлучивања СФПС-а је приближно линеаран, док је у случајевима динамичких окружења раст варијација времена завршетака у функцији времена трајања одлучивања ЦППС-а нелинеаран. 